\title{
Vida, morte, paixão e processo em Clarice Lispector
}

\section{Luiz Antonio Mousinho ${ }^{1}$}

Resumo: Procuraremos rastrear algumas das representações do tema da morte em narrativas de Clarice Lispector, seja no seu sentido mais básico, com o topos da finitude da vida, seja noutro motivo recorrente, o da vida mal vivida, automatizada, alienada, imersa em solidões desnaturadas. Num esforço sobretudo narratológico de leitura, daremos atenção especial às categorias narrador, focalizador e personagem. As relações entre ficção e sociedade também nos servirão como amparo teórico, com o rastreamento das vozes sociais entranhadas nas narrativas trazendo o social (em sentido amplo) para a fatura literária.

Palavras-chave: Clarice Lispector. Vida. Morte. Narratologia.

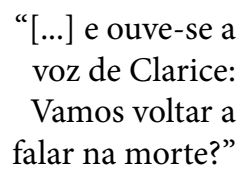

Contam de Clarice Lispector - João Cabral de Melo Neto

$\mathrm{s}$ aniversários de nascimento e morte de Clarice Lispector ocorrem em dezembro e seu último livro lançado em vida, $A$ hora da estrela, saiu no mesmo mês em que a escritora partiu. A novela confirma a presença de um dos temas mais recorrentes na obra da autora: a morte. Seja no seu sentido mais básico, com o topos da finitude da vida, seja noutro motivo recorrente, o da vida mal vivida, automatizada, alienada, a morte-em-vida de relações sociais rotinizadas e imersas em solidões desnaturadas. Em alguns de seus textos, a visão da morte revelada pela construção literária corre paralela a uma percepção da vida a ser vivida

1 Professor Titular da Universidade Federal da Paraíba, onde atua como professor do Departamento de Comunicação, do Programa de Pós-Graduação em Letras/ PPGL (mestrado de doutorado) e do Programa de Pós-graduação em Comunicação e Culturas Midiáticas/ PPGC (mestrado). 
como um processo interminável e inevitável, no qual a morte e a dor são elementos intrínsecos.

Daremos especial atenção no artigo à novela $A$ hora da estrela; aos contos Feliz aniversário, Os laços de família e $\mathrm{O}$ jantar, do volume Laços de família; e ao romance A paixão segundo G.H., trazendo remissões a outros romances, contos e crônicas da autora. Buscaremos observar as estruturas narrativas para ver como são construídos textualmente os temas abordados, investigando assim de maneira pontual as narrativas, com atenção aos campos semânticas da morte e vida. Ao mesmo tempo, observaremos como o constructo ficcional vai dialogando com o tecido contextual, com a série social.

Vamos rastrear algumas das representações do tema da morte (CHEVALIER; GHEERBRANT, 2020) em interface com a vida nos textos referidos da escritora, procurando realizar uma leitura sobretudo narratológica, com atenção às categorias narrador e focalizador (GENETTE, 2017), personagem (CANDIDO et al.), entre outras, tomadas de maneira bem mais pontual (como tempo e espaço). As relações entre ficção e sociedade também nos servirão como amparo teórico, com o rastreamento das vozes sociais entranhadas nas narrativas, trazendo o social (em sentido amplo) para a fatura literária.

Conforme assinalam Ella Shohat e Robert Stam (2006, p.264) a "literatura [...] não se refere ao 'mundo' mas representa suas linguagens e discursos". Dialogando com o pensamento de Mikhail Bakhtin, os autores lembram que a arte é inegavelmente social não porque representa o real, mas porque “constitui uma 'enunciação' situada historicamente uma rede de signos endereçados por um sujeito ou sujeitos constituídos historicamente para outros sujeitos constituídos socialmente". (SHOHAT; STAM, 2006, p.265).

No interesse da crítica e tomando a lição de Antonio Candido (2000, p.8), o elemento social deve observado nas obras "não exteriormente [...] 
mas como fator da própria construção artística”. Conforme a formulação do autor, "[...] o externo (no caso, o social), importa, não como causa, nem como significado, mas como elemento que desempenha um certo papel na constituição da estrutura, tornando-se, portanto, interno" (CANDIDO, 2000 , p. 6). Ressaltamos que no presente texto, o termo social não se referirá exclusivamente aos outros sociais (pobres e miseráveis), tão evidentes num país abissalmente desigual como o Brasil, mas também às relações familiares em extratos de classe média, tema de boa parte das narrativas abordadas.

Jean Chevalier e Alain Gheerbrant (2020) rastreiam alguns sentidos culturalmente construídos em torno das noções de vida e morte. Para os autores, se a morte "designa o fim absoluto de qualquer coisa de positivo", ela "também é a introdutora aos mundos desconhecidos [...] o que revela a sua ambivalência [...] e a aproxima, de certa forma, dos ritos de passagem". (CHEVALIER; GHEERBRANT, 2020, p.694). Assim ela "é revelação e introdução. Todas as iniciações atravessam uma fase de morte, antes de abrir o acesso a uma vida nova". Conforme Chevalier e Gheerbrant, "nesse sentido, ela tem um valor psicológico: ela liberta das forças negativas e regressivas, ela desmaterializa e libera as forças de ascensão do espírito. Se ela é, por si mesma, filha da noite e irmã do sono, ela possui, como sua mãe e seu irmão, o poder de regenerar". (CHEVALIER; GHEERBRANT, 2020, p.694).

Ainda segundo os autores, se "o ser que ela abate vive apenas no nível material ou bestial, ele fica na sombra dos Infernos; se, ao contrário, ele vive no nível espiritual, ela lhe revela os campos da luz". Assim, os "místicos [...] notaram que em todo ser humano, em todos os seus níveis de existência, coexistem a morte e a vida, isto é, uma tensão entre duas forças contrárias. A morte em um nível é talvez a condição de uma vida superior em outro nível”. (CHEVALIER; GHEERBRANT, 2020, p.694).

A ambivalência e a coexistência das pulsões de vida e morte estão 
densamente discutidas por Freud em Além do princípio do prazer (1987) e são apontadas no trecho citado acima como afins a outros campos de conhecimento. Levando em conta a presença de um misticismo não sectário nem dogmático em Clarice Lispector ${ }^{2}$, vamos procurar observar em momentos de algumas de suas obras como se corporificam em linguagem literária aspectos dessa ambivalência, buscando rastrear alguns de seus mecanismos de produção de sentido, com base na narratologia.

\section{Sangue e música, vida e morte}

Em A arte como procedimento, V. Chklovski (1976), um dos formalistas russos, resgata trechos de um diário de Leon Tolstoi, onde é sentido o encobrimento do mundo apequenado na automatização da vida cotidiana banalizada. Nele, Tolstoi, se vê num momento sufocado pelo hábito, na rotina de repetir gestos mecânicos. A "vida complexa de muita gente se desenrola [...] como se esta não tivesse sido", escrevia Tolstoi, vendo a vida perdida em movimentos não percebidos, embotada na morte-emvida da banalidade diária. (CHKLOVSKI, 1976, p.44).

Concluía Chklovski (1976, p.44): "assim a vida desaparecia, se transformava em nada. A automatização engole os objetos, os hábitos, os móveis, a mulher e o medo à guerra". E, completava, no trecho talvez mais conhecido do famoso ensaio: "E eis que para devolver a sensação de vida, para sentir os objetos, para provar que pedra é pedra, existe o que se chama arte". O autor complementa defendendo que o "objetivo da arte é dar a sensação do objeto como visão e não como reconhecimento, o procedimento da arte é o procedimento da singularização dos objetos e o procedimento que consiste em obscurecer a forma, aumentar a dificuldade

2 Conforme sugestão de Suzi Frankl Sperber, em diálogo de orientação de projeto de doutorado, ocorrido em 2000. 
e a duração da percepção". (CHKLOVSKI, 1976, p.45).

Poderíamos invocar o pensamento de Mikhail Bakhtin como contrapeso para este viés interpretativo que contempla a questão da desautomatização como ainda estimulante e operativa. Como assinala Robert Stam, Bakhtin não deixava de saudar a noção de arte como procedimento, "onde a vida social é expressa no interior de um material semiótico definido e na linguagem específica de um meio" (STAM, 1992, p.25). No entanto, havia divergências. O afastamento, como percebe Stam, entre Bakhtin e os formalistas, estava na hierarquização e separação total, não aceita por Bakhtin, entre linguagem prática e linguagem poética. Por outro lado, a noção formalista de linguagem como luta entre dois tipos de discurso se chocava com a noção bakhtiniana de "heteroglossia, a ideia de que cada língua nacional compreende, na realidade, um sem número de sublinguagens". (STAM, 1992, p. 26). A "hostilidade mecânica em relação ao velho" também estaria fora do mapa de Bakhtin. Assim como a simples inversão de valores existentes, com a excessiva valorização dos meios técnicos, em resposta ao gesto do realismo ingênuo de apenas olhar o conteúdo (STAM, 1992, p. 25).

$\mathrm{Na}$ novela $A$ hora da estrela, a lida da linguagem no rumo de reacender a vida e desentorpecer os sentidos se coloca de maneira tensa, mas sem rompimentos com a tradição. Como assinala Roberto Corrêa dos Santos, não se pode ligar a obra de Clarice às "retóricas da destruição literária. Não lhe interessa zerar o texto, e sim dispará-lo. Fazer a língua ela mesma, nausear-se". Por essa via, "desse imenso vômito, dessa convulsão do corpo por ter de se expressar, resulta um gasto e um uso. Gasto e uso de energia, gasto e uso dos detritos, que enfim ganharão a forma devida”. (SANTOS, 1991, p.60). Assim, para Santos, a

forma aí exacerba a sua característica de ser um movimento em direção ao exterior. Torna-se o próprio exterior, a exposição que não esconde os andaimes, o 
'antes da obra', nem o trabalho, nem o suor. O prazer e a beleza implicam a história do fazer. O ofegante exercício de ir dispondo, acertando, corrigindo. A beleza recusa o sentimento plácido das artes findas. A beleza é registro do tumulto. É a sombra da mesa cheia de papéis soltos. (SANTOS, 1991, p.60).

A hora da estrela desvela o processo de construção literária como uma via-crucis similar ao processo de vida. O narrador Rodrigo SM coloca em cena os papéis soltos à mesa (1990, p.31), assume sua dificuldade no entendimento dos outros sociais os quais aborda em sua escrita e, consequentemente, os entraves na redação ("sei que estou adiando a história e brinco de bola sem bola [...] Mas desconfio que toda essa conversa é feita apenas para adiar a pobreza da história, pois estou com medo").

Rodrigo SM desenha o seu exílio existencial que se delineia, vagarosa e penosamente, ao lado do desterro dos personagens que cria Olímpico e Macabéa e toda uma horda de seres à margem, parafusos sociais "facilmente substituíveis" (LISPECTOR, 1990, p.28) e despidos até mesmo de "pobreza enfeitada" (LISPECTOR, 1990, p.35), posto que o narrador se recusa a promover uma glamourização da desgraça, exibindo uma miséria em meio-termo: "A moça [...] pelo menos comida não mendigava, havia toda uma subclasse de gente mais perdida e com fome”. (LISPECTOR, 1990, p.45).

A agônica aproximação do escritor Rodrigo S.M. com seus personagens se fará pela intuição e, sobretudo, pelo reconhecimento do estado de deserdados que compartilham, em esferas diversas, com S.M. tendo consciência de seu desterro e de suas criaturas. "Escrevo por não ter nada a fazer no mundo: sobrei e não há lugar para mim na terra dos homens. Escrevo porque sou um desesperado e estou cansado [...] e se não fosse a sempre novidade de escrever, eu me morreria simbolicamente todos os dias". (LISPECTOR, 1990, p.35-36). E ainda: "Mas preparado estou para 
sair discretamente pela saída da porta dos fundos. E agora só quereria ter o que eu tivesse sido e não fui”. (LISPECTOR, 1990, p.36). Essa identificação com esse outro social - na errância, na perdição, na solidão, vai levar o narrador personagem ao espanto e à náusea ao refletir, no final do livro, sobre a morte da personagem Macabéa. “- Meu Deus, só agora me lembrei que a gente morre/ Mas - mas eu também?!” (LISPECTOR, 1990, p.106).

Em A hora da estrela vários elementos apontam para o inevitável movimento de vida e morte. A música, por exemplo, aparece no texto (1990b, p.68) como possibilidade intuitiva de entendimento ("através da música, adivinhava talvez que havia outros modos de sentir, havia existências mais delicadas e até com um certo luxo de alma"); e como prenúncio de vida e prolepse (antecipação narrativa) do advento da morte: "o violino é um aviso. Sei que quando eu morrer vou ouvir o violino do homem e pedirei música, música, música”. (LISPECTOR, 1990, p.101).

Outro elemento recorrente na novela literária é o sangue, que aparece na obra como elemento vivificador e como indiciador de morte, síntese de vida e morte. Sua presença vem na dedicatória (1990, p.21) assinada por Clarice Lispector (“à cor rubra e escarlate como o meu sangue de homem em plena idade e portanto dedico-me a meu sangue"); no impulso criativo do encontro do narrador Rodrigo S.M. com a vida de Macabéa: "sangue arfante de tão vivo". (LISPECTOR, 1990, p.26); com o "sangue pálido" (menstrual) (1990, p.39) disfarçado nas roupas da personagem de vida desbotada; no pavor de vampiros impingido pela tia na infância (1990, p.40); no gosto de Olímpico por sangue: "Uma vez fora ao cinema e estremecera da cabeça aos pés quando vira a capa vermelha. Não tinha pena do touro. Gostava era de ver sangue". (LISPECTOR, 1990-b, p.62).

Em Macabéa, o nariz sangra após uma queda e ela fala no seu horror de ver sangue no cinema (LISPECTOR, 1990, p.70), enquanto o sangue da carne no açougue estimula Olímpico: ("meter a faca na carne o excitava”) (LISPECTOR, 1990, p.70). Já Glória, colega de trabalho de Macabéa, 
tinha "no sangue um bom vinho português e também era amaneirada no bamboleio do caminhar por causa do sangue africano escondido". (LISPECTOR, 1990, p.70). Isso além do batom vermelho que borra a boca de Macabéa à maneira de sangue, como se "grosso sangue lhe tivesse brotado dos lábios”. (LISPECTOR, 1990, p.79). Essas e várias outras ocorrências se fazem presentes na narrativa, incluindo a hora da morte da protagonista caída na sarjeta. "E da cabeça um fio de sangue inesperadamente vermelho e rico. $\mathrm{O}$ que queria dizer que apesar de tudo ela pertencia a uma resistente raça anã teimosa que um dia vai talvez reivindicar o direito ao grito", pulsão de vida brotando na hora da morte. (LISPECTOR, 1990, p.98-99).

A presença da morte como decorrência da vida está posta ainda em A hora da estrela, desde a "Dedicatória autor": "Pois que dedico esta coisa aí ao antigo Schumann e sua doce Clara que são hoje ossos, ai de nós". (LISPECTOR, 1992, p.21). Já o nome da personagem Macabéa, em um de seus sentidos, reforça essa noção. A expressão macabra é derivada de macabeu, numa referência aos Macabeus, povos guerreiros representados na Bíblia. Sabe-se, porém, que a expressão dança macabra se referia, na Idade Média, a pinturas murais "em que se via enorme cortejo de pessoas de ambos os sexos, de todas as idades e condições sociais, dirigidas pela figura da morte". (BUENO, 1965, p. 70). Assim, dança macabra seria originada de dança dos Macabeus. No livro, a coreografia mórbida de Macabéa, da vida reificada.

\section{A receptividade ao existir}

O tema da morte também vai ser uma constante no volume de contos Laços de família. Em Amor, se na natureza o que há de selvagem é sentido como parte harmônica do funcionamento daquele mundo que não nega a violência nem a morte como parte do processo da vida, o ambiente da cultura parece firmar sentidos unívocos e opositivos. Enquanto na natureza 
as coisas estão postas de forma crua, a crueldade inatural existente na civilização é maquiada, envernizada, garantindo a superfície, com a morte e a violência submersas sob o peso de uma naturalização que assoma na vida automatizada.

O conto Feliz aniversário sintetiza bem uma das facetas da tematização da morte na obra. Trata-se da revelação de como as relações familiares se tecem, no mais das vezes, como algo sem sentido, estagnado, estéril. Tal desnudamento se dá no espaço-tempo da comemoração dos 89 anos da "mãe de todos", da "matriarca" da família.

$\mathrm{Na}$ narrativa, o trato com o tempo revela muito desse processo de embotamento da vida. No conto, o tempo é visto como algo a ser aflitivamente vencido, ultrapassado, durante o ritual convencional da festa. Assim, os personagens se esbatem em cena numa angustiada espera do seu tenso fluir em meio à reunião familiar e, ao mesmo tempo, buscam valorizá-lo como algo dotado de sentido após consumado, mal vivido quando se cumpre.

Teso, lento, o tempo é empregado em pequenas ocupações e dissimulações que evitam o enfrentamento de diferenças e ressentimentos entre os pares familiares que pairam no espaço-tempo de convívio do aniversário da matriarca da família. A figura ruinosa da velha é vista posta no centro da sala como um marco e uma lembrança do tempo fossilizado de que "cada ano vencido era uma vaga etapa da família toda". (LISPECTOR, 1983, p.64).

Ao cortar seubolode aniversário, a aniversariante expõe cacos devigor, dando "a primeira talhada com punho de assassina". (LISPECTOR, 1983, p.64). A violência com a qual a velha manipula a faca assinala sua oscilação entre a potência e a ruína. (SANTOS, 1986). O gesto surpreendente choca a sua nora de Ipanema, sem saber se ficava "escandalizada ou agradavelmente surpreendida. Estava um pouco horrorizada”. (LISPECTOR, 1983, p.87). A reação dos parentes de $\mathrm{D}$. Anita não tarda e na narrativa é mostrado como 
eles avançam em força dominadora para o bolo: "Dada a primeira talhada, como se a primeira pá de terra tivesse sido lançada, todos se aproximaram de prato na mão, insinuando-se em fingidas acotoveladas de animação, cada um para sua pazinha” (LISPECTOR, 1983, p.67).

O enunciado "como se a primeira pá de terra tivesse sido lançada", remete a ritos fúnebres e demonstra a agressividade com a qual cada um assume sua posição em relação à velha em ruínas e, a exemplo das frases "punho de assassina" (LISPECTOR, 1983, p.67) e "como um morto se levanta devagar" (LISPECTOR, 1983, p.68), convergem para campos semânticos que cruzam prenúncio de morte com relações de poder postas em cena.

O estado do bolo da festa vai marcando a passagem do tempo do ritual em família no conto. O "bolo inteiro", o "enorme bolo açucarado" passa a ser visto como o "bolo apagado, grande e seco", se dispersa em "farelos secos" e termina como "o bolo desabado". Mas o movimento do bolo entre a integridade e a ruína vai sobretudo metaforizar o percurso entre a vida e a morte. Isso não só como marcação de início e fim e sim visto em um processo de coexistência, ressaltando-se aí a valorização do processo, aspecto bastante caro e recorrente na obra de Clarice Lispector.

A variação de estados do bolo é posta em estranha simbiose com o poder que aos poucos vai sendo percebido emanando da figura ruinosa da velha. A inteireza do bolo anima a recomposição do que resta de potência nela, animada pela reiteração dos filhos de que "ela era a mãe"("Hoje é o dia da mãe!). Tal lembrança vai sendo absorvida e assumida aos poucos, o que é apontado em passagens salteadas da narrativa. Assim, o bolo desaba ("o bolo já desabado"), mas entre seus escombros a velha percebe que "ela era a mãe", "Ela era a mãe", "Ela, a forte". "E se de repente não se ergueu, como um morto se levanta devagar e obriga mudez e terror aos vivos, a aniversariante ficou mais dura na cadeira e mais alta”. (1983, p.68).

A marcação do elemento seco é recorrente em vários contos de 
Laços de família e aqui se faz presente na descrição do bolo da festa. Em seu aspecto negativo, o elemento seco dissemina o sentido de infertilidade, criado no texto pelo recorrente uso de lugares-comuns, signo de automatização e mecanicismo nas relações entre pares familiares durante a festa de aniversário. Isso se faz mesmo a partir do título do conto, grafado sem a exclamação que traduz (ou simula) entusiasmo. O próprio título do livro, Laços de família, encerra um lugar-comum. Os diálogos e as posturas encenadas durante o aniversário, guardam o tom de coisa desgastada, clicheizada. Porém a forma como tais elementos que perderam o viço são ativados com várias facetas do texto, afiam uma visão em torno da morteem-vida estabelecida na convivência. $\mathrm{O}$ uso de lugares-comuns denuncia o que há de artificial e morto na vida familiar, vista em sua banalização cotidiana.

A inserção na narrativa do olhar dos personagens também acontece com a pergunta reiterada "E Cordélia?", que lembra esta indagação interiorizada da velha, pensando no seu neto eleito e na sua nora, posta em toda a narrativa a guardar o silêncio, em meio ao jogral de frases feitas, não-ditos, palavras vazias proferidas ininterruptamente pelos outros parentes. O neto Rodrigo vai permanecer presente na indagação da velha e em sua certeza de que ao menos aquele "seria um homem". (1983, p.68). Já a mãe do garoto será vista sempre meio distante, discretamente alheia a toda aquela encenação que paira na festa: "Cordélia olhava ausente para todos, sorria”. (LISPECTOR, 1983, p.67).

Ela será, aliás, a única personagem no conto a experimentar o privilégio e o desespero da epifania, tão recorrente em outros contos de Clarice Lispector. Este instante de descoberta vai se dar num olhar dirigido à velha, encerrada naquela

mudez que era sua última palavra. Com um punho fechado sobre a mesa, nunca mais ela seria apenas o que ela pensasse. Sua aparência afinal a ultrapassara e, 
superando-a, se agigantava serena. Cordélia olhou-a espantada. $\mathrm{O}$ punho mudo e severo sobre a mesa dizia para a infeliz nora que sem remédio amava talvez pela última vez: é preciso que se saiba. É preciso que se saiba. Que a vida é curta. Que a vida é curta. (LISPECTOR, 1983, p.73).

A verdade profunda atinge Cordélia num átimo e se esvai, "Porque a verdade era um relance”. (1983, p.73). O luxo da percepção privilegiada se mostra como uma chance rara, o que aumenta a angústia de Cordélia, que olha "para trás implorando à velhice ainda um sinal de que uma mulher deve, num ímpeto dilacerante, enfim, agarrar a sua derradeira chance de viver". Assim, "mais uma vez Cordélia quis olhar./ Mas a esse novo olhar a velha era uma velha à cabeceira da mesa". (LISPECTOR, 1983, p.73). A última frase do período citado já vem noutro parágrafo, assinalando de maneira forte, na linguagem, a oportunidade já perdida quando Cordélia tenta olhar mais uma vez.

Cordélia também é a eleita da velha, ela, "a nora mais moça”. Aí, percebe-se, por inversão, um forte intertexto com o Rei Lear de Shakespeare. $\mathrm{Na}$ tragédia, a filha mais nova do rei é deserdada pelo amor sincero e sem palavras devotado ao pai, amor desarmado dos ardis adormecidos nas palavras fáceis das irmãs Goneril e Regane, que lhe amealham os bens. Aflita por não conseguir explicitar este amor silencioso e profundamente sincero ("Que poderá fazer Cordélia?...Amar e ficar calada") a filha Cordélia debate-se na dor da impossibilidade de outra forma de procedimento na demonstração de amor ao pai ("estou mais do que certa de que meu amor é mais rico do que a minha linguagem"). (SHAKESPEARE, s/d, p.138-139).

No conto Feliz aniversário, embora seja nora, e não filha, a personagem da mesma forma preserva o silêncio de seu amor profundo, seu sentido de afirmação, contra o falseamento das palavras codificadas e embaciadas - mortas -, proferidas pelos parentes. O neto Rodrigo, tem na etimologia de seu nome o sentido de "senhor da glória", tendo origem na 
palavra germânica Roderico ( $r i k=$ senhor + hrod $=$ da glória), transformado na forma popularizada na língua portuguesa (BUENO, 1965). O sentido do nome do personagem confirma seu papel de um dos mais fortes elementos de reafirmação da vida.

A palavra glória é destacada por Benedito Nunes como uma das mais recorrentes na obra da autora.

A palavra glória - uma das mais frequentemente empregadas em Clarice Lispector - também marca, na concepção do mundo da autora, o limite do dizível [...] A sensação das coisas sem interferência do entendimento, "dissolvendo seu mistério", têm uma "qualidade de glória" [...] Epifania do ser ou sua perfeição, a 'glória' que assinala a receptividade ao que existe, está relacionada a outros termos de sentido teológico: "júbilo e estado de Graça”. Convém lembrar as acepções de glória no Antigo Testamento: poder, refulgência, esplendor, majestade, sintetizando aparição, a manifestação ou a epifania do ser divino. (NUNES, 1989, p.125).

O nome de Rodrigo confirma sua posição de detentor da senha para a vida, a ser vivida em suas profundezas, sentido consagrado na obra de Clarice Lispector nos momentos epifânicos, de descortínio silencioso (NUNES, 1976, p.94). A presença silenciosa do personagem e de sua mãe, Cordélia, selam como que um convite à possibilidade de se viver algo além do ritual de repetir gestos mecânicos.

Roberto Corrêa dos Santos percebe uma simetria fundamental na relação entre o neto, a velha e Cordélia, a simbolizar a passagem de vida e morte e, mais ainda, os caminhos possíveis entre a vida e a morte.

o neto escolhido, filho de Cordélia, simboliza o outro extremo da velhice, a infância. No centro desta nova relação, encontra-se Cordélia por decidir. Assim, pode-se reapresentar o seguinte fio a estruturar as 
forças entre as quais se encontra a figura ausente de Cordélia: Velha (morte) - Cordélia - Rodrigo (vida). Através da imagem da morte, a personagem Cordélia, a nora mais moça recebe e lê a mensagem de vida, estreitamente ligada à de amor. Mensagem não expressa pelas palavras, mas pelo gesto inscrito no punho da aniversariante [...] Cordélia, entre os dois polos (a morte e a vida), é a única a decifrar o mistério da velha. (SANTOS, 1986, p.70).

$\mathrm{O}$ autor ressalta ainda que a personagem opta pelo caminho da vida, representado pelo filho. Filho que, com um gesto, a arrasta pela mão, “paciente e insistente”. (LISPECTOR, 1983, p.73).

Como já se assinalou aqui, Feliz aniversário ativa vários campos semânticos, notadamente o ligado à noção de morte (em oposição ao elemento vida) revelada ora pelo elemento seco, ora por palavras como desabar (e sinônimos), indiciando ruína, o que aparece em referência ao bolo, à velha e ao filho José ("sua altura parecia desmoronável") (LISPECTOR, 1983, p.76). Reforçando o campo semântico da vida, estão palavras e situações que acentuam o sentido de potência, de ímpeto, como a ocasião do vigor do neto ao soprar o bolo e sobretudo da velha, vista "com a mão fechada sobre a toalha como se ela encerrasse um cetro" (p.72). "Ela a forte" (LISPECTOR, 1983, p.68), se "agigantava serena" (LISPECTOR, 1983, p.72). Misto de potência e ruína, a velha sintetiza bem a luta entre a vida e a morte e oscila entre o exercício e o despojamento absoluto do poder.

Seu mutismo de esfinge perturba pelo que introduz de misterioso e indecifrável no que se quer domado, familiar. Assim, na hora da saída, cada um dos beijos que lhe é dado pelos parentes se arma de cautela, "como se sua pele tão infamiliar fosse uma armadilha”. (LISPECTOR, 1983, p.72) Essa duplicidade entre o familiar e o estranho é o que torna a presença da velha por vezes tão embaraçosa para os parentes, perplexos e temerosos 
ante o desconhecido, traduzido nesse alheamento e em sua forma mais radical na morte, espelhada na sua figura ruinosa. Afinal, a "morte era seu mistério" (LISPECTOR, 1983, p.76).

\section{Liberdade e náusea, potência e ruína}

No conto Os laços de família o tema da morte vai ser tocado de viés, pela percepção do envelhecimento e da passagem do tempo sem que a vida seja vivida em plenitude, com a impossibilidade de que se intercambie em experiência (BENJAMIN, 2012), que se expresse "aquilo que é mais verdadeiro", como é dito no prólogo de A hora da estrela (LISPECTOR, 1990, p.22). O envelhecimento da mãe da protagonista é sutil e lentamente esboçado, até ser percebido e filtrado na narrativa pela percepção da filha, personagem focalizadora. Lembramos que a focalização se refere à representação da informação "que se encontra ao alcance de um determinado campo de consciência, seja do narrador, seja de um personagem". (REIS; LOPES, p.246-47). É o olhar do personagem ou do narrador, como ele percebe e filtra a história (como percebe a história para além do sentido da visão). No episódio da freada do táxi, Catarina percebe sua mãe "de repente envelhecida e pobre" (LISPECTOR, 1983, p.119), envelhecimento também notado na janela do trem e, em seguida, quando da queda do seu chapéu, "deixando aparecer apenas a nova dentadura" (LISPECTOR, 1983, p.122).

Noutro momento, Catarina torna a notar a fragilização de sua mãe de "rosto usado", experimentando um esboço de inversão de papéis na dependência que as liga e submete. Se sua independência em relação à mãe chega a lhe causar um certo prazer, este logo se transforma em náusea: "Ninguém pode te amar senão eu, pensou a mulher rindo pelos olhos; e o peso da responsabilidade deu-lhe à boca um gosto de sangue". (LISPECTOR, 1983, p.120).

No caminho para a estação para a despedida da mãe que estivera 
hospedada com a protagonista Catarina (e seu marido e filho), após um fluir tenso e lento do tempo na viagem de táxi, a narrativa ganha velocidade e tremenda dramaticidade com o apito do trem que anuncia a despedida. Além dessa aceleração narrativa (GENETTE, 2017), aparece aí um forte apelo visual que marca um tom cinematográfico inequívoco, com planos que captam a aflição das duas personagens pela urgência do não dito e, ao mesmo tempo, colhem imagens do que se passa em volta e está alheio e indiferente àquele átimo de intensa e angustiada ligação entre mãe e filha.

mamãe! disse a mulher. Catarina! disse a velha. Ambas se olhavam espantadas, a mala na cabeça de um carregador interrompeu-lhes a visão e um rapaz correndo segurou de passagem o braço de Catarina, deslocando-lhe a gola do vestido. Quando puderam ver-se de novo, Catarina estava sob a iminência de lhe perguntar se não esquecera de nada.../ - ...Não esqueci de nada? perguntou a mãe. (LISPECTOR, 1983, p.121).

A ansiedade das duas mulheres é entrecortada por imagens de personagens e situações exteriores ao drama da despedida, com a aflição ressaltada por um tratamento espacial (e temporal também) que mostra pessoas apressadas e indiferentes, atentas apenas ao chamado da saída do trem. A configuração do espaço (LINS, 1976) é marcada pela indiferença dos figurantes e sua pressa, no momento mesmo em que as duas personagens do conto vivem algo indefinível e fundamental, no instante em que acham que poderiam parar finalmente para dizer alguma coisa uma à outra. Isso amplia a angústia de um tempo subjetivo descompassado com a súbita urgência supérflua assumida pelo mundo em volta. A dramaticidade do momento se agrava na impossibilidade de dizer algo. No final desta passagem do conto, mais uma frase banal quebra a expectativa, indicando a insuficiência da linguagem num instante crucial, indiciando o fracasso das relações e a inversão dos papéis familiares. 
Também a Catarina parecia que haviam esquecido de alguma coisa, e ambas se olhavam atônitas porque se realmente haviam esquecido, agora era tarde demais. Uma mulher arrastava uma criança, a criança chorava, novamente a campainha soou... Mamãe, disse a mulher. Que coisa tinham esquecido de dizer uma à outra, e agora era tarde demais. Parecia-lhe que deveriam um dia ter dito assim: sou tua mãe Catarina. E ela deveria ter respondido: e eu sou tua filha”. / - Não vá pegar corrente de ar! gritou Catarina" (LISPECTOR, 1983, p.121).

“- Ora menina, sou lá criança”, é a frase com a qual a mãe responde à filha, nessa carinhosa, aflita e sintomática troca de papéis. Em poucas linhas adiante, a intensa impossibilidade de comunicação entre as duas é exposta com impacto na revelação da cisão entre o que se passa na mente de Catarina e nas palavras que lhe vem aos lábios ("Catarina teve subitamente vontade de lhe perguntar se fora feliz com seu pai: / - Dê lembranças a titia! gritou”). (LISPECTOR, 1983, p.121).

Nesse momento a pontuação confere uma força extrema à narrativa. Os dois pontos levam a expectativa ao leitor de que a personagem irá desabafar disparando a delicadíssima pergunta que subitamente lhe aparece atravessada na garganta. No entanto, sua fala (“- Dê lembranças a titia") quebra violentamente tal expectativa. A pontuação amplia ao máximo, expressivamente, a percepção da angustiada impossibilidade da personagem em recuperar o tempo de dizer o não-dito. No lento percurso do táxi e na pressa da despedida vê-se um tempo que se arrasta para além do ter algo a dizer e outro que parece faltar no momento do se ter o que dizer, mesmo sem se saber como e o quê.

Roberto Corrêa dos Santos (1986, p.54) percebe no conto O jantar, também de Laços de família, a tensão entre vida e morte construída no olhar nauseado do narrador-personagem, posto durante toda a narrativa a observar um homem maduro comendo, suas pausas, suas vacilações, seu 
vigor, sua falta de fôlego, seus suores, o abandono do ato de comer com o repouso dos talheres, sua força nas retomadas, seus engasgos durante $\mathrm{o}$ ato, seus signos de poder inscritos no corpo. E a morte desenhada no envelhecimento, no enfrentamento vacilante do comer a carne, do beber o vinho.

Expressões do campo semântico (RASTIER, 1975) do poder, da força e do vigor predominam no conto. $\mathrm{O}$ homem é visto sob a focalização (GENETTE, 2017) do narrador-personagem, como chegando ao restaurante certamente vindo de ocupações com "grandes negócios". Percebido como sendo "alto, corpulento", de cabelos brancos, "sobrancelhas espessas e mão potentes", trazendo no dedo "o anel de sua força", se sentando "amplo e sólido". O "velho engrandecido", o "velho comedor de crianças" por vezes vacila no ato de se alimentar, mas volta sempre "refeito e duro". De "mão pesada e cabeluda", "queixo ativo", visto "em plena glória do jantar, mastigando de boca aberta, passando a língua pelos dentes". (LISPECTOR, 1983, p.88).

Entremeando o campo semântico da solidez, da força, da potência, tem-se o da fraqueza, do desmoronamento, da ruína. O que é indiciado pela queda de um talher, pelo respirar com dificuldade, o mastigar devagar de um "ancião", um "velho [que] se imobiliza" com o "peito contraído e barrado", adiante "respirando, acabado", noutro instante com "traços caídos e dementes" ou de olhos cerrados: "o patriarca estava chorando por dentro". (LISPECTOR, 1983, p.92).

Ao final, a oscilação entre potência e ruína (SANTOS, 1986) se acirra na hora da saída do restaurante quando, enxugando os olhos "fazendo caretas e inúteis e penosas", alisa os cabelos brancos "com poder" e se levanta "segurando o bordo da mesa com as mãos vigorosas". Porém, "liberto de um apoio ele parece mais fraco, embora ainda enorme”. (LISPECTOR, 1983, p.92).

O sentido etimológico da palavra epifania tem origem religiosa, 
significando "aparecimento ou manifestação reveladora de Deus ou de divindade", sendo em sentido laico "manifestação ou percepção da natureza ou do significado essencial de uma coisa" ou "apreensão da realidade por meio de algo geralmente simples e inesperado". (HOUAISS; VILLAR, 2001, p.1178). Em literatura e especificamente na obra de Clarice Lispector epifania "é expressão de um momento excepcional, em que se rasga para alguém a casca do cotidiano, que é rotina, mecanicismo e vazio" (SÁ, 1979, p.106). São os súbitos vislumbres de realidades recalcadas, adormecidas, que eclodem não raro em meio à modorra e à banalidade cotidianas.

Em O jantar, o desestabilizar-se do narrador protagonista provém de uma "inquietante estranheza - estado que resulta da mudança de percepção sobre algo, antes familiar, tornado agora subitamente absurdo" (SANTOS, 1986, p.55). No caso, a visão do viver em sua rotina embaciada e finitude, do poder e sua derrocada, da vida e suas muitas mortes.

Configura-se assim o trânsito entre o estranho e o familiar tão recorrente em Laços de família e em vários outros momentos da prosa clariceana. Ainda em O jantar, observa Roberto Corrêa dos Santos (1986, p.55), a brusca recusa de comer e o sentimento de perdição no narrador personagem (pela lágrima vista no rosto do velho), indicam angústia e o impasse pelo reconhecimento no outro do "dilema do homem, a permanente batalha entre viver e morrer" (1986, p.54). Por outra via, o autor também indica, com argúcia, a indagação da possibilidade de leitura complementar do conto pela senda do "desmoronamento de um poder de autoridade masculina”. (SANTOS, 1986, p.57).

No conto, num dos momentos de maior agudeza perceptiva e de inscrição do estranho na normalidade, a amplificação de luzes e sons, recorrente em outros textos de Clarice, assoma quando o "restaurante parecia irradiar-se com dupla força sob o tilintar dos vidros e talheres; na dura coroa brilhante da sala os murmúrios cresciam" (1983, p.90). No fechamento do texto, o homem observado pelo narrador-focalizador 
“atravessa o aspecto luminoso do salão, desaparece”. (LISPECTOR, 1983, p.93).

E o narrador protagonista, para além da desestabilização que o tomara por toda a narrativa, sintetiza, numa atitude provisória de recusa, sua postura perante a existência, sua rejeição temporária do caminhar, seu jejum viável, pausa para ser possível retomar a vida. Com a certeza de um caminho a ser trilhado. "Mas sou um homem ainda", diz o personagem numa frase que forma um parágrafo. E, no seguinte, a narrativa se conclui: "Quando me traíram ou assassinaram, quando alguém foi embora para sempre, ou perdi o que de melhor me restava, ou quando soube que vou morrer - eu não como. Não sou ainda esta potência, esta construção, esta ruína. Empurro o prato, rejeito a carne e seu sangue”. (LISPECTOR, 1983, p.92).

\section{Considerações finains}

As narrativas clariceanas oscilam com frequência entre um sentido de afirmação ou negação da vida em sua finitude, em sua precariedade e seus impasses. $\mathrm{O}$ protagonista de $\mathrm{O}$ jantar diz não por instantes (ao ato de comer, ao mundo, à vida), pois não aguenta vislumbrar o destino comum da morte, ao observar os engasgos de um velho numa refeição. A personagem de Os obedientes, conto de Felicidade clandestina, não suporta o dente quebrado e diz não definitivamente ao viver, assim como a mulher que vaga pelo zoológico em $\mathrm{O}$ búfalo, procurando seu ponto de ódio, e só achando amor derramado em volta. Rodrigo SM, narrador-protagonista de $A$ hora da estrela, se farta de tudo e diz não ao processo de vida, mas diz sim de novo, no princípio e ao final. Ana, do conto Amor entrega-se à vitalidade infernal do Jardim e depois volta para casa: não e sim, à vida comum, à vida em comum.

Cordélia, de Feliz aniversário, guarda um sentido de afirmação da 
vida que está em seu silêncio, na recusa humilde do que no solo seco e certo das palavras é traição e morte, sugerida que está no conto a rejeição da palavra-clichê e também uma "visão da morte apontando para a urgência de viver", para falar com Cleusa Passos (1991, p.173). Martim, do romance A maçã no escuro, se isola em rejeição à profissão, à família, a todos os vínculos anteriores, mas se expande em desejo quanto ao mundo lá fora, ao silêncio das plantas, ao ruminar das vacas, ao sexo possível, à volta para casa. Catarina, de Os laços de família, se recolhe na presença do marido e da mãe, tolhe-se, mas depois expande seu ser em trânsito pelas ruas sentidas em suas larguezas, corpo aberto para a vida e o espaço, em intenso flerte com as coisas do mundo.

Já em A paixão segundo G.H., a valorização da vida como processo vai se dar de maneira estritamente ligada à visão do específico humano da linguagem, vista a um só tempo como fracasso e glória, ao indiciar a impossibilidade de fusão com o ilimitado. Após a desistência da busca de identidade com o outro representado pela barata, a personagem $\mathrm{GH}$ percebe que existe "a trajetória, e a trajetória não é apenas um modo de ir. A trajetória somos nós mesmos. Em matéria de viver, nunca se pode chegar antes. A via-crucis não é apenas um descaminho, é a passagem única, não se chega senão através dela e com ela" (LISPECTOR, 1986, p.172)

Num momento anterior da narrativa, G.H. já propusera a "aceitação cruel da dor, a solene falta de piedade pelo próprio destino, amar mais o ritual de vida que a si próprio" (1986. p.116) ${ }^{3}$. É só através do "malogro da voz" ${ }^{4}$ que a personagem vai chegar a assinalar a aceitação da sua natureza,

3 João Camillo Penna assinala que a barata se apresenta a G.H. como "possibilidade [da] atualidade absoluta" representada pelo "acasalamento entre Deus e o Homem de que fala Hoelderlin" (Penna, 1987, p.2) e em "oposição à estrutura de adiamento da 'esperança' sobre a qual se organiza sempre sua vida anterior, projetando o presente para um momento futuro". O autor defende que, "num mundo sem Deus a única forma de divindade é o próprio tempo enquanto espera e diferimento do instante para mais tarde." (PENNA, 1987. p.4).

4 Camillo Penna também afirma que G.H. “termina por aceitar o limite imposto pela sua espécie que reduz o campo da fusão amorosa ao âmbito humano, fazendo-a desistir de querer ser o outro e aceitar sua essência limitada humana - a linguagem - o que a levará a escrever a experiência”. (PENNA, 1987, p.3). 
"onde a dor não é apenas uma coisa que nos acontece mas o que somos" e "vivê-la é a nossa paixão. A condição humana é a paixão de Cristo" (1986, p.171).

Na crônica Menino à bico de pena, publicada no Jornal do Brasil em 1968, as negociações de afeto entre mãe e filho, com seus acordos e ciladas, vão sendo assumidas no olhar da mãe mirando o mistério da criança em formação, no sondar da narrativa da interioridade do menino, com variação da focalização: "farei a barganha de ser amado, é inteiramente mágico chorar para ter em troca: mãe”. (1992, p.257). E assinala o laço que prende e une, a senha para a sobrevivência, a vida e o amor, em suas várias feições: "o ruído familiar entra pela porta e o menino, mudo de interesse pelo que o poder de um menino provoca, para de chorar: mãe. Mãe é não morrer". (LISPECTOR, 1992, p.257).

No ensaio A paixão de Clarice Lispector, Benedito Nunes (1987) assinala que a obra clariceana "ultimar-se-á em $A$ hora da estrela na identificação da narradora com Macabéa”, marcando um retorno do místico ao ético. (NUNES, 1987, p.279). Em A hora da estrela a crueza ante a lembrança da morte pede como resposta a reflexão da vida como um processo inevitável e a ser vivido como processo. A morte-em-vida de Macabéa e a solidão de Rodrigo S.M. esperam uma "resposta que espero que alguém no mundo ma dê. Vós?” (LISPECTOR, 1990, p.22).

A última palavra do livro, que forma o último parágrafo, é: Sim. Isso remete à primeira frase da novela que lembra que "tudo começou com um sim”. (1990, p.25). Antes dessa afirmação final, porém, o narrador se debate mais uma vez com a visão da morte. A náusea do momento revelador, no entanto, leva a uma visão aguda das contingências da vida e de sua urgência de ser vivida como um processo inevitável e interminável que, enquanto se dá, não pode ceder à não-vida, à vida imersa em morte, exilada. "Não esquecer que por enquanto é tempo de morangos. Sim". (LISPECTOR, 1990, p.106). 
Chevalier e Gheerbrant (2020, p.695) lembram que a "morte tem inúmeras significações. Liberadora das penas e preocupações, ela não é um fim em si; ela abre o acesso ao reino do espírito, à vida verdadeira; mors janua vitae (a morte, porta da Vida)". Para os autores, no "sentido esotérico, ela simboliza a mudança profunda por que o homem passa sob o efeito da Iniciação [...] A décima terceira lâmina do Tarô simboliza a morte em seu sentido iniciático de renovação e de nascimento". Além disso, "depois do Enforcado místico, inteiramente oferecido e abandonado, que retomava forças ao contato com a terra, a Morte nos lembra que é preciso ir ainda mais longe e que ela própria é a própria condição para o progresso e para a vida”. (CHEVALIER; GHEERBRANT, p.695).

Clarice morreu após escrever $A$ hora da estrela. Benedito Nunes (1988, p.280) vê a novela como "momento de verdade" onde a "paixão de Clarice Lispector torna-se compaixão; o pathos solitário converte-se em simpatia como forma de padecimento comum, unindo até o extremo da morte, in extremis, a narradora com a moça nordestina anônima”.

Em Clarice, a vida é vivida como busca, numa procura que se sabe interminável. Fadada ao fracasso, tal demanda também se reveste de glória, que reside na própria busca. Assim a vida é uma procura a ser vivenciada sem objetivos finalistas, como processo que vale por si, como busca. Nas páginas finais de $A$ hora da estrela, o narrador sugere: "Mas que não se lamente os mortos: eles sabem o que fazem". (LISPECTOR, 1992, p.104). Um pouco adiante na jornada da narrativa, o narrador ousa garantir, num tom trivial que revitaliza o lugar-comum cotidiano, que "o melhor negócio é ainda o seguinte: não morrer, pois morrer é insuficiente, não me completa, eu que tanto preciso". (1990, p.105). Por enquanto é tempo de morangos: sim.

\section{Referências}


BENJAMIN, Walter. O narrador. In: BENJAMIN, Walter. Magia e técnica, arte e política: ensaios sobre literatura e história da cultura. Tradução Sérgio Paulo Rouanet. São Paulo: Brasiliense, 2012.

BUENO, Francisco da Silveira. Grande dicionário etimológico-prosódico da língua portuguesa. São Paulo: Saraiva, 1965. vol. 3.

CANDIDO, Antonio. Literatura e sociedade. São Paulo: Publifolha, 2000.

CHEVALIER, Jean; GHEERBRANT, Alain. Tradução Vera da Costa e Silva et al. Dicionário de símbolos. Rio de Janeiro: José Olympio, 2020.

CHKLOVSKI, Victor. A arte como Procedimento. In: EIKHENBAUN, B. et al. Teoria da Literatura: formalistas russos. Tradução Antnio Hohlfeldt et al. Porto Alegre: Globo, 1973. p.39-56.

GENETTE, Gérard. Figuras III. Tradução Ana Alencar. São Paulo: Estação Liberdade, 2017.

HOUAISS, Antônio; VILLAR, Mauro de Salles. Dicionário Houaiss da língua portuguesa. Rio de Janeiro: Objetiva, 2001.

LINS, Osman. Lima Barreto e o espaço romanesco. São Paulo: Ática, 1976.

LISPECTOR, Clarice. A descoberta do mundo. Rio de Janeiro: Francisco Alves, 1992.

LISPECTOR, Clarice. A hora da estrela. Rio de Janeiro: Francisco Alves, 1990.

LISPECTOR, Clarice. Laços de família. Rio de Janeiro: Nova Fronteira, 1983.

NUNES, Benedito. O drama da linguagem: uma leitura de Clarice Lispector. São Paulo: Ática, 1989.

NUNES, Benedito. O mundo imaginário de Clarice Lispector. In: O dorso 
do tigre. São Paulo: Perspectiva, 1976. p. 93-139.

NUNES, Benedito. Introdução e nota filológica. LISPECTOR, Clarice. A paixão segundo GH/ Clarice Lispector. Ed. Crítica/ Benedito Nunes, coord. Paris, Association Archives de la littérature latino-américáine, des Caraibes et africaine du XXe.; Brasília, DF, CNPq, 1988. p.XXIV-XXXVIII.

PASSOS, Cleusa. Clarice Lispector: os elos da tradição. Revista USP, n. 10, p. 167-174, jun./jul./ago. 1991. Disponível em: www.revistas.usp.br/revusp/ article/view/52192. Acesso em: 24 jun. 2017.

PENNA, João Camillo. A imitação da barata. Folha de S Paulo, São Paulo, 18 set. 1987. Folhetim, Caderno B, no 567, p.2-4.

RASTIER, François. Sistemática das isotopias. In: GREIMAS, A.J. Ensaios de semiótica poética. São Paulo: Cultura/ Edusp, 1975.p.96-125.

REIS, Carlos; LOPES, Ana Cristina. Dicionário de teoria da narrativa. São Paulo: Ática, 1988.

SÁ, Olga de. A escritura de Clarice Lispector. Petrópolis: Vozes/ Faculdades Integradas Tereza D’Avila, 1979.

SANTOS, Roberto Corrêa dos. Artes de fiandeira. In: Laços de família. Rio de Janeiro: Francisco Alves, 1991. p. 5-14.

SANTOS, Roberto Corrêa dos. Clarice Lispector. São Paulo: Atual, 1986. (Série Lendo).

SHAKESPEARE, William. Rei Lear. Tradução J. Costa Neves. Rio de Janeiro; São Paulo; Porto Alegre: W.M. Jackson, s/d. (Col. Clássicos Jackson).

SHOAHAT, Ella; STAM, Robert. Crítica da imagem eurocêntrica. Tradução de Marcos Soares. São Paulo: Cosac Naify, 2006.

STAM, Robert. Bakhtin: da teoria literária à cultura de massa. Tradução Heloísa Jahn. São Paulo: Ática, 1992. 
Life, death, passion and process in Clarice Lispector

Abstract: We aim to track down some of the representations on the theme of death in Clarice Lispector's narratives, whether it is in its most basic sense, with the topos of life's finiteness, whether it is in another recurring motif, the poorly lived life, automatized, alienated, immersed in unnatural solitudes. In an effort above all narratological of reading, we will pay special attention to the categories of narrator, focalizer and character. The relations between fiction and society will serve as theoretical support to us, with the tracking down of social voices intermingled in narratives leading the social (in a broad sense) to the literary fortune.

Keywords: Clarice Lispector. Life. Death. Narratology.

Recebido em: 10/04/2021

Aceito em: 16/09/2021 